\title{
EDITORIAL
}

\section{Multilevel approaches toward understanding antisocial behavior: Current research and future directions}

\author{
MANDI L. BURNETTE ${ }^{a}$ AND DANTE CICCHETTI ${ }^{b, c}$ \\ ${ }^{a}$ University of Rochester; ${ }^{b}$ Institute of Child Development, University of Minnesota; and ${ }^{c}$ Mt. Hope Family Center, University of \\ Rochester
}

Antisocial behavior is multifaceted and has a rich history of research. Nearly two decades have passed since Richters and Cicchetti (1993a) co-edited a Special Issue in this Journal entitled, "Toward a Developmental Perspective on Conduct Disorder." At that time, researchers in the field examined questions such as the utility of taxonomies in defining antisocial behavior (Hinshaw, Lahey, \& Hart, 1993; Richters \& Cicchetti, 1993b), the developmental processes associated with the emergence of antisocial behavior in children (Loeber et al., 1993), emerging literature on the neuropsychology of antisocial behavior (Moffitt, 1993; Pennington \& Bennetto, 1993), gender differences in antisocial behavior (Zahn-Waxler, 1993; Zoccolillo, 1993) and the role of attachment and families in the etiology of antisocial behavior (Greenberg, Speltz, \& Deklyn, 1993; Waters, Posada, Crowell, \& KengLing, 1993). The issue ended by presenting some fresh approaches to the treatment of antisocial behavior in youth (Dodge, 1993; Kazdin, 1993). At the time of publication, these manuscripts contributed a great deal to the literature on antisocial behavior, propelling the field forward into new and exciting directions.

Much has changed since the publication of that Special Issue. Advances in quantitative theory and practice have made it increasingly possible to account for heterogeneity within those who exhibit antisocial behavior using person-centered analyses and growth curve analyses (Nagin, 1999, 2005). We now have a greater understanding of the varied developmental pathways by which youth come to exhibit antisocial behavior (Campbell et al., 2010; Mulvey et al., 2010). However, this literature is relatively new, and more work is needed

Work on this Special Issue was supported by grants from the National Institute on Drug Abuse (DA017741) and the Spunk Fund, Inc.

Address correspondence and reprint requests to: Mandi Burnette, Department of Clinical and Social Sciences, University of Rochester, RC Box 270266, 460 Meliora Hall, Rochester, NY 14627; E-mail: mandi.burnette@ rochester.edu; or Dante Cicchetti, Institute of Child Development, University of Minnesota, 51 East River Road, Minneapolis, MN 55455; E-mail: cicchett@umn.edu. in order to understand the variability in the development of antisocial behavior.

Researchers have also begun to incorporate multiple levels of analysis in their approach to studying antisocial behavior, particularly the intersection of biological and environmental influences on antisocial behavior (Cicchetti, 2008). We now understand that genetic vulnerabilities for violence may be moderated by extreme environmental events, such as childhood maltreatment (Caspi et al., 2002; Jaffe et al., 2004; Kim-Cohen et al., 2006; Mead, Beauchaine, \& Shannon, 2010). The literature has moved toward understanding how distinct physiological patterns, such as low resting heart rate, may help us to further understand differences in risk for antisocial behavior (Baker et al., 2009). In this issue, authors build upon the existing research to apply a multilevel approach toward understanding antisocial behavior across many developmental periods, using a number of different phenotypic expressions of antisocial behavior (e.g., aggression, substance use).

As the field has become more multidimensional, models of how antisocial behavior develops have also become more comprehensive and innovative. Cascade approaches have highlighted the dynamic role of early experience in influencing later outcomes (Cicchetti \& Tucker, 1994; Masten \& Cicchetti, 2010). Such approaches have been combined with existing models to investigate how early risk factors may impact functioning across multiple domains and levels of analysis to influence antisocial behavior. Studies have examined how early experiences shape brain development, neurotransmitter functioning, temperament, and neuroendocrine functioning, which may in turn influence antisocial behavior (Cicchetti, 2002; Gunnar \& Vazquez, 2006; Mead et al., 2010). The role of gender, attachment, and parent-child relationships can now be examined within broader contextual models of antisocial behavior. The articles in this issue share an innovative spirit and test novel theories among populations at varying levels of risk from young childhood to samples of incarcerated offenders. 
Finally, the challenge in the field of antisocial behavior has been to translate this research into effective interventions. Much of this work has been informed by the literature on early parent-child relationships, examining how reducing maternal depressive symptoms (Shaw, Connell, Dishion, Wilson, \& Gardner, 2009) and changing parenting practices (Forgatch, Patterson, Degarmo, \& Beldavs, 2009) may impact risk for antisocial behavior. We have asked the contributors in this Special Issue to consider the implications of their research for informing interventions.

In sum, the field of antisocial behavior has come a long way, but we still have far to go. In putting together this Spe-

\section{References}

Baker, L. A., Tuvblad, C., Reynolds, C., Zheng, M., Lozano, D. I., \& Raine, A. (2009). Resting heart rate and the development of antisocial behavior from age 9 to 13: Genetic and environmental influences. Development and Psychopathology, 21, 939-960.

Campbell, S. B., Spieker, S., Vandergrift, N., Belsky, J., Burchinal, M., \& Rhe NICHD Early Child Care Research Network. (2010). Predictors and sequelae of trajectories of physical aggression in school-age boys and girls. Development and Psychopathology, 22, 133-150.

Caspi, A., McClay, J., Moffitt, T., Mill, J., Martin, J., Craig, I. W., et al. (2002). Role of genotype in the cycle of violence in maltreated children. Science, 297, 851-854.

Cicchetti, D. (2002). How a child builds a brain: Insights from normality and psychopathology. In W. Hartup \& R. Weinberg (Eds.), Minnesota symposia on child psychology: Vol. 32. Child psychology in retrospect and prospect (pp. 23-71). Mahwah, NJ: Erlbaum.

Cicchetti, D. (2008). A multiple-levels-of-analysis perspective on research in development and psychopathology. In T. P. Beauchaine \& S. P. Hinshaw (Eds.), Child and adolescent psychopathology (pp. 27-57). New York: Wiley.

Cicchetti, D., \& Tucker, D. (1994). Development and self-regulatory structures of the mind. Development and Psychopathology, 6, 533-549.

Dodge, K. A. (1993). The future of research on the treatment of conduct disorder. Development and Psychopathology, 5, 311-319.

Forgatch, M. S., Patterson, G. R., Degarmo, D. S., \& Beldavs, Z. G. (2009). Testing the Oregon delinquency model with 9-year follow-up of the Oregon Divorce Study. Development and Psychopathology, 21, 637-660.

Greenberg, M. T., Speltz, M. L., \& Deklyn, M. (1993). The role of attachment in the early development of disruptive behavior problems. Development and Psychopathology, 5, 191-213.

Gunnar, M. R., \& Vazquez, D. (2006). Stress neurobiology and developmental psychopathology. In D. Cicchetti \& D. Cohen (Eds.), Developmental psychopathology: Vol. 2. Developmental neuroscience (2nd ed., pp. 533-577). Hoboken, NJ: Wiley.

Hinshaw, S. P., Lahey, B. B., \& Hart, E. L. (1993). Issues of taxonomy and comorbidity in the development of conduct disorder. Development and Psychopathology, 5, 31-50.

Jaffe, S. R., Caspi, A., Moffitt, T. E., Polo-Tomas, M., Price, T. S., \& Taylor, A. (2004). The limits of child effects: Evidence for genetically mediated child effects on corporal punishment but not on physical maltreatment. Developmental Psychology, 40, 1047-1058.

Kazdin, A. E. (1993). Treatment of conduct disorder: Progress and directions in psychotherapy research. Development and Psychopathology, 5, 277-310. cial Issue, we sought to bring together researchers from disparate areas in order to provide a comprehensive perspective on the field of antisocial behavior. Contributors were encouraged to use innovative techniques and models, to consider the role of multilevel influences across multiple domains, and to reflect upon how their work could inform treatment and future research on antisocial behavior. The result is a collection of articles that we hope will prompt new ideas and questions about the study of antisocial behavior in the decades ahead.

Kim-Cohen, J., Caspi, A., Taylor, A., Williams, B., Newcombe, R., Craig, I. W., et al. (2006). MAOA, maltreatment, and gene-environment interaction predicting children's mental health: New evidence and a meta-analysis. Molecular Psychiatry, 11, 903-913.

Loeber, R., Wung, P., Keenan, K., Giroux, B., Southamer-Loeber, M., Van Kammen, W. B., et al. (1993). Developmental pathways in disruptive child behavior. Development and Psychopathology, 5, 103-133.

Masten, A. S., \& Cicchetti, D. (2010). Developmental cascades. Development and Psychopathology, 22, 491-495.

Mead, H. K., Beauchaine, T. P., \& Shannon, K. E. (2010). Neurobiological adaptations to violence across development. Development and Psychopathology, 22, 1-22.

Moffitt, T. E. (1993). The neuropsychology of conduct disorder. Development and Psychopathology, 5, 135-151.

Mulvey, E. P., Steinberg, L., Piquero, A. R., Besana, M., Fagan, J., \& Schubert, C. (2010). Trajectories of desistance and continuity in antisocial behavior following court adjudication among serious adolescent offenders. Development and Psychopathology, 23, 453-475.

Nagin, D. S. (1999). Analyzing developmental trajectories: A semi-parametric, group-based approach. Psychological Methods, 4, 139-177.

Nagin, D. S. (2005). Group-based modeling of development. Cambridge, MA: Harvard University Press.

Pennington, B. F., \& Bennetto, L. (1993). Main effect of transactions in the neuropsychology of conduct disorder? Commentary on "the neuropsychology of conduct disorder." Development and Psychopathology, 5, 153-164.

Richters, J. E., \& Cicchetti, D. (1993a). Toward a developmental perspective on conduct disorder. Development and Psychopathology, 5, 1-4.

Richters, J. E., \& Cicchetti, D. (1993b). Mark Twain meets DSM-III-R: Conduct disorder, development, and the concept of harmful dysfunction. $D e$ velopment and Psychopathology, 5, 5-29.

Shaw, D. S., Connell, A., Dishion, T. J., Wilson, M. N., \& Gardner, F. (2009) Improvements in maternal depression as a mediator of intervention effects on early childhood problem behavior. Development and Psychopathology, 21, 417-439.

Waters, E., Posada, G., Crowell, J., \& Keng-Ling, L. (1993). Is attachment theory ready to contribute to our understanding of disruptive conduct problems? Development and Psychopathology, 5, 215-224.

Zahn-Waxler, C. (1993). Warriors and worriers: Gender and psychopathology. Development and Psychopathology, 5, 79-89.

Zoccolillo, M. (1993). Gender and the development of conduct disorder. Development and Psychopathology, 5, 65-78. 